\title{
Determining Radionuclide Emissions from Unmonitored Sources
}

by

M. C. Thompson

Westinghouse Savannah River Company

Savannah River Site

Aiken, South Carolina 29808

J. T. Hamilton

B. C. Blunt

This paper was prepared in connection with work done under the above contract number with the U.S. Department of Energy. By acceptance of this paper, the publisher and/or recipient acknowledges the U.S. Government's right to retain a nonexclusive, royalty-free license in and to any copyright covering this paper, along with the right to reproduce and to authorize others to reproduce all or part of the copyrighted paper. 


\section{DISCLAIMER}

This report was prepared as an account of work sponsored by an agency of the United States Government. Neither the United States Government nor any agency thereof, nor any of their employees, makes any warranty, express or implied, or assumes any legal liability or responsibility for the accuracy, completeness, or usefulness of any information, apparatus, product, or process disclosed, or represents that its use would not infringe privately owned rights. Reference herein to any specific commercial product, process, or service by trade name, trademark, manufacturer, or otherwise does not necessarily constitute or imply its endorsement, recommendation, or favoring by the United States Government or any agency thereof. The views and opinions of authors expressed herein do not necessarily state or reflect those of the United States Government or any agency thereof.

This report has been reproduced directly from the best available copy.

Available to DOE and DOE contractors from the Office of Scientific and Technical Information, P.O. Box 62, Oak Ridge, TN 37831; prices available from (615) 576-8401.

Available to the public from the National Technical Information Service, U.S. Department of Commerce, 5285 Port Royal Road, Springfield, VA 22161. 


\section{DISCLAIMER}

Portions of this document may be illegible in electronic image products. Images are produced from the best available original document. 
WSRC-TR-95-0378

Revision 1

\section{Determining Radionuclide Emissions From} Unmonitored Sources (U)

Martha C. Thompson

James T. Hamilton

Brent C. Blunt 
WSRC-TR-95-0378

Revision 1

\section{Determining Radionuclide Emissions From Unmonitored Sources (U)}

Date:

Prepared by:

Reviewed by:

July 14,1999

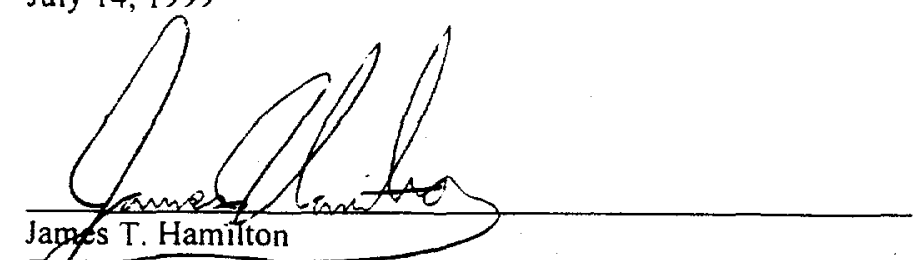

Environmental Protection Department

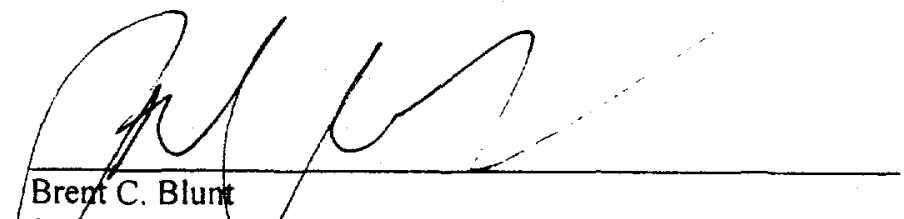

SBS Radionuclige NESHAPS Coordinator

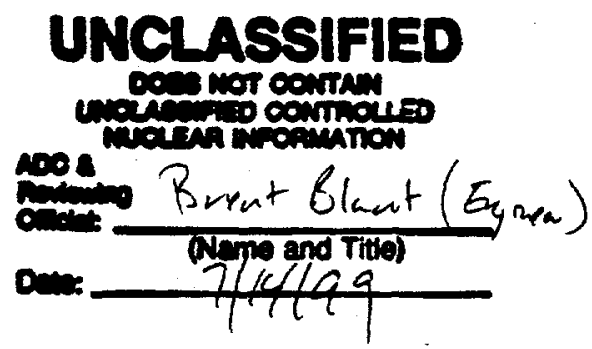

Westinghouse Savannah River Company

Savannah River Site

Aiken, SC 29808 


\subsection{PURPOSE AND SCOPE}

This document presents standard methods to be used in the calculation of air emissions from unmonitored sources. These calculation methods are used for the evaluation of emissions from unmonitored sources which include Category III point sources, inactive sources, and non-point sources. These calculations are used for determination of the air emissions for compliance with the Savannah River Site Air Emissions Inventory (SRS AEI). The uncontrolled emissions from these calculations shall also be used for input into an EPA-approved computer model. Currently, SRS is using the Clean Air Act Assessment Package-1988 (CAP-88). This model assesses the highest off-site dose (effective dose equivalent) to the maximally exposed off-site individual. The results from the model (in the annual NESHAPs report) are submitted to EPA headquarters and the regional office by June 30 for the previous calendar year in accordance with 40 CFR 61.94(a). The methods outlined here are alternate (rather than measurement) procedures for determining emissions in accordance with 40 CFR 61.93(b)(3).

\subsection{DOE ORDER APPLICABILITY}

\section{$2.1 \quad$ DOE Orders}

\subsection{General Environmental Protection Program}

2.1.2 5400.5 Radiation Protection of the Public and the Environment

2.1.3 5480.4 Environmental Protection, Safety, and Health Protection Standards

2.1.4 6430.1A General Design Criteria

\section{$2.2 \quad$ DOE Guides}

2.2.1 DOE/EH-0173T, Environmental Regulatory Guide for Radiological Effluent Monitoring and Environmental Surveillance

2.2.2 DOE/EP-0096, A Guide for Effluent Radiological Measurements at DOE Installations

\subsection{NATIONAL CODES AND STANDARDS APPLICABILITY}

\subsection{ANSI Standards}

3.1.1 N13.1-1969, Guide to Sampling Airborne Radioactive Materials in Nuclear Facilities

\subsection{Code of Federal Regulations}

3.2.1 40 CFR 61 Subpart A, NESHAP - General Provisions

3.2.2 40 CFR 61 Subpart H, National Emission Standards for Emissions of Radionuclides Other Than Radon from Department of Energy Facilities

\subsubsection{CFR 61 Appendix D, Methods for Estimating} Radionuclide Emissions

3.2.4 10 CFR 20 Appendix B, Annual Limits On Intake (ALIs) and Derived Air Concentrations (DACs) of Radionuclides for Occupational Exposure; Effluent Concentrations; Concentrations for Release to Sewerage

3.2.5 10 CFR 30.72 Schedule C-Quantities of radioactive materials requiring consideration of the need for an emergency plan for responding to a release.

\subsection{DEFINITIONS}

\subsection{Terms}

Activity - Amounts of radioactive material are usually expressed in units of activity, which is the rate of radioactive decay. The commonly used unit is the curie ( $\mathrm{Ci}$ ) which is $3.73 \times 10^{10}$ disintegrations per second (Reference 6.16).

Air Changes - The number of times the volume in a particular room (the volume of air in the room) is replaced by the ventilation system. Air changes (or air exchanges) are usually expressed on a per hour basis.

Category I - Category I sources are point sources having the potential to cause an annual effective dose equivalent (EDE) to the public of greater than $0.1 \mathrm{mrem}$ ( $1 \%$ of the [40 CFR 61.92] 10 mrem standard). These sources require continuous emissions monitoring (Reference 6.7). All radionuclides, which could contribute greater than $10 \%$ of the potential EDE for a release point shall be, measured (Reference 6.4).

Category II - Category II sources are point sources with the potential to cause an EDE of greater than $0.01 \mathrm{mrem} / \mathrm{yr}$ and less than or equal to $0.1 \mathrm{mrem} / \mathrm{yr}$. The Category II sources require continuous proportional sampling or an annual grab sample to confirm that emissions remain below $0.1 \mathrm{mrem}$ (Reference 6.7).

Category III - Category III point sources may effect an EDE of less than or equal to $0.01 \mathrm{mrem} / \mathrm{yr}$ and do not require 
emissions monitoring. Rather, emissions from these sources are submitted in an annual report based on process knowledge and the past 12 months of operations. Although not required, sampling/monitoring can be substituted for the annual report if desired (Reference 6.7).

Confinement factor - Per Reference 6.9, the confinement factor (C) takes into consideration whether the material is confined while the worker is present or whether it is handled in the open.

Effective dose equivalent (EDE) - The sum of the products of absorbed dose and appropriate factors to account for differences in biological effectiveness due to the quality of radiation and its distribution in the body of reference man (Reference 6.6).

Half-life - The half-life of a radionuclide is the time required for the activity to decrease to one half of the original (Reference 6.16).

Inactive source - An inactive source is a source in which the process design function is no longer being utilized. An inactive source is in a shutdown mode, typically awaiting decontamination and decommissioning. An inactive source does not lend itself to evaluation by traditional stack sampling and monitoring techniques (Reference 6.3).

Nearest Receptor - The distance from each emission point to any member of the public at any offsite point where there is a residence, school, business, or office (Reference 6.8).

Non-point sources - Sources without well defined, single exhaust points.

Point Source - A point source is an emission source with a well-defined single exhaust point, such as a stack or vent (Reference 6.3).

Potential Effective Dose Equivalent (PEDE) - The dose to the public from a radionuclide emission source which could be effected if all pollution control equipment did not exist, but operations were otherwise normal (Reference 6.4). The evaluation of SRS sources for PEDE based on 1991 data (with release height and true distance from site boundary included in the model) is contained in Reference 6.5 .

Radioactivity - Radioactivity is atomic emissions resulting from natural or artificial nuclear transformation. The energy is emitted in the form of $\alpha, \beta$, or $\gamma$ rays. The physical state or chemical combination of the element does not affect radioactivity. The nature of the energy radiation's, their energy, and the half-life of the process (Reference 6.16) characterizes the radioactivity of a nuclide.
Radionuclide - A radionuclide is an isotopic form of an element (either natural or artificial) that undergoes spontaneous radioactive decay (Reference 6.4).

Release fraction - The fraction of radioactive material likely to be released into the workplace breathing air, as determined by its physical and chemical form (Reference 6.9). For the purposes of this document, it is regarded as the fraction of radioactive material likely to be released to the air (workplace or otherwise) from the unmonitored source.

Resuspension factor - The fractional amount of contamination on one square meter of floor or that will enter one cubic meter of air and presumably be respirable by any person (over an extended period of time), either outdoors within large contaminated areas; or indoors with smaller contaminated areas. A factor of $10^{-6} \mathrm{~m}^{-1}$ is used generally as a conservative value for radiation protection purposes. Additional experience pertinent to a specific operation and the judgment of experienced professionals should be considered where available for specific nuclides and types of industrial activity (Reference 6.1).

\subsection{Acronyms \\ CFR Code of Federal Regulations \\ EDE Effective Dose Equivalent \\ PEDE Potential Effective Dose Equivalent \\ SRS Savannah River Site}

\subsection{GUIDES}

\subsection{Modified NUREG 1400 Method}

NUREG 1400 (Reference 6.9) provides a method for calculation of emissions where an inventory of radionuclides is available. NUREG 1400 was developed for the determination of potential intake of radionuclides in the workplace. The method is modified here for determination of the emissions of radionuclides. Emissions are estimated based on maximum inventory, in curies ( $\mathrm{Ci}$ ), of material at the source. Potential emissions are determined by adjusting for the physical state of the material and mathematically removing any pollution control equipment. NUREG 1400 does provide a method for determining when personnel air sampling is needed. However, section 1.2 of NUREG 1400 provides methods for determining the amount of material that may be inhaled, which is the concentration of such material in the room air.

First, the maximum inventory (in $\mathrm{Ci}$ ) for each radionuclide that is available for release must be determined. Per 
Appendix D to Part 61, 2(a), radioactive materials in sealed packages that remain unopened, and have not leaked during the assessment period should not be included in the calculation.

\subsubsection{Release Fraction ( $R$ )}

The release fraction ( $R$ ) is the fraction of the radioactive material likely to be released into the workplace, as determined by its physical and chemical form (Reference 6.9). For the purposes of this document, it is regarded as the fraction of radioactive material, which due to its physical state, is likely to be released to the air (workplace or otherwise) from the unmonitored source. The release fraction values for physical state adjustment defined in NUREG 1400 are listed below.

- 1 for gases

- $10^{-2}$ for liquids or particulate solids

- $10^{-3}$ for solids.

If any nuclide is heated to a temperature of 100 degrees Celsius or more, boils at a temperature of 100 degrees Celsius or less, or is intentionally dispersed into the environment (interpreted as the atmosphere), it must be considered to be a gas (per 40 CFR 61 Appendix D 2(b)).

At sources where the material is in a variety of physical forms (e.g., liquid, solid, gaseous) and the proportions are not known, the physical form providing the highest emissions estimate is assigned to all materials. Where the proportions are known, an appropriate ratio is used to derive the source term (Reference 6.3).

\subsubsection{Dispersibility (D)}

Other factors may be utilized when deemed necessary. Dispersibility may be appropriate to consider for some emission points. Dispersibility comes from adding energy to the system through grinding, milling, boiling, or exothermic chemical reactions. A dispersibility factor (D) of 10 can be applied to the calculation if cutting, grinding, heating, or chemical reactions of materials are performed (Reference 6.9).

\subsubsection{Confinement Factor (C)}

Though Reference 6.9 applies a confinement factor, this factor will be neglected, as it will be assumed to be 1 for all releases. The confinement factor (C) takes into consideration whether the material is confined while the worker is present or whether it is handled in the open. A confinement factor would be one hundredth of the material handled in a glovebox, one tenth of the material handled in a well-ventilated hood, and one for material handled in an open work area (it is a control factor). The method utilizing the confinement factor was derived for intake of radionuclides (Reference 6.9). To modify this method for potential release, the confinement factor is always assumed to be 1 . The technically results in all the potential release being available for personnel intake. However, for emissions purposes, it is assumed that all the potential release being available for release. Since we often have interest in both uncontrolled and controlled releases, the confinement factor will not be used, and the control factor will be used when calculating controlled releases only as outlined below.

\subsubsection{Control Factor}

5.1.4.1 If a control device is installed between the place of use and the point of release, the uncontrolled emissions are adjusted by multiplying by a control factor as shown in the following table. The division operation effectively removes any pollution control equipment.

5.1.4.2 The application of the control factors (from Appendix D of 40 CFR 61) in the following table, rather than utilizing the manufacturer efficiency claims, permits conservatism and EPA acceptance as required in 40 CFR 61.93 (b)(3). The control factor is an approximation of the radionuclide fraction not caught by any abatement equipment (filters, etc.) through which the facility air passes before release to the atmosphere.

\begin{tabular}{|l|l|l|}
\hline Controls & $\begin{array}{l}\text { Types and/or } \\
\text { Physical State }\end{array}$ & $\begin{array}{l}\text { Control factor } \\
\text { (CF) }\end{array}$ \\
\hline HEPA filters & Particulates & 0.01 \\
\hline Fabric filter & Particulates & 0.1 \\
\hline Sintered metal & Particulates & 1 \\
\hline $\begin{array}{l}\text { Activated carbon } \\
\text { filters }\end{array}$ & Iodine gas & 0.1 \\
\hline $\begin{array}{l}\text { Douglas bags: } \\
\text { Held one week or } \\
\text { longer for decay. }\end{array}$ & Xenon & $0.5 / \mathrm{wk}$ \\
\hline $\begin{array}{l}\text { Douglas bags: } \\
\text { Released within } \\
\text { one week. }\end{array}$ & Xenon & 1 \\
\hline Venturi scrubbers & Particulates & 0.05 \\
\hline Venturi scrubbers & Gases & 1 \\
\hline $\begin{array}{l}\text { Packed bed } \\
\text { scrubbers }\end{array}$ & Gases & 0.1 \\
\hline $\begin{array}{l}\text { Electrostatic } \\
\text { precipitators }\end{array}$ & Particulates & 0.05 \\
\hline Xenon traps & Xenon & 0.1 \\
\hline Fume hoods & All & 1 \\
\hline Vent stacks & All & 1 \\
\hline
\end{tabular}


Control factors and efficiency are related by the following equation:

$\mathrm{CF}=1-\mathrm{eff}$

where CF is the control factor and eff is the efficiency (expressed as a decimal, not a percentage) of the abatement device to remove the specified contaminants.

5.1.4.3 If the air does not pass through any abatement equipment prior to release to the atmosphere, the control factor is considered to be unity. This means that the uncontrolled and controlled release values are the same.

5.1.4.4 If there is a series of control equipment (i.e., a train) used for the abatement of the source, the overall control factor is obtained by multiplying the appropriate control factors as follows.

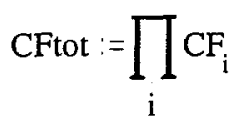

where $\mathrm{CF}_{\mathrm{i}}$ gives the individual control factors and $\mathrm{CF}$ tot is the overall control factor.

For example, if an abatement train consists of a fabric filter in series with two subsequent HEPA filters, the overall control factor for the train is determined as follows.

CFtot $=\mathrm{CF}_{1} * \mathrm{CF}_{2} * \mathrm{CF}_{3}$

Cftot $=0.1 * 0.01 * 0.01$

CFtot $=1 * 10^{-5}$

where $\mathrm{CF}_{1}, \mathrm{CF}_{2}$ and $\mathrm{CF}_{3}$ are the fabric filter control factor, the first HEPA control factor, and the second HEPA control factor, respectively.

5.1.4.5 If, however, there is more than one abatement train in parallel, the train, which has the largest (most conservative) control factor, will be used in the calculations.

\subsubsection{Total Emissions (Modified NUREG 1400 Method) \\ The total uncontrolled emissions are calculated by the following equation:}

Uncontrolled release $(\mathrm{Ci} / \mathrm{yr})=$

Radionuclide inventory $(\mathrm{Ci}) * 10^{-6} * \mathrm{R} * \mathrm{D} * \mathrm{C}$

Controlled release $(\mathrm{Ci} / \mathrm{yr})=$

(Radionuclide inventory $(\mathrm{Ci})^{*} 10^{-6} * \mathrm{R} * \mathrm{D} * \mathrm{C}$ )/CFtot

where $\mathrm{R}, \mathrm{C}$, and $\mathrm{D}$ are defined above. $\mathrm{C}$ is assumed to be 1 so that the equation simplifies to:

Uncontrolled emissions $(\mathrm{Ci} / \mathrm{yr})=$

Radionuclide inventory $(\mathrm{Ci}) * 10^{-6} * \mathrm{R} * \mathrm{D}$

Controlled emissions $(\mathrm{Ci} / \mathrm{yr})=$

(Radionuclide inventory $\left.(\mathrm{Ci}) * 10^{-6} * \mathrm{R} * \mathrm{D}\right) / \mathrm{CF}$ tot

\subsubsection{The Brodsky Factor}

The factor of $10^{-6}$ in the above equations (modified from Reference 6.9) is the Brodsky factor (Reference 6.1). As described in Reference 6.9 , a worker is not expected to achieve an intake exceeding $10^{-6}$ of the material being handled. This factor is defined as the maximum fractional amount of plant throughput (or inventory) that one employee takes in via inhalation (or ingestion, which is likely to be lower). The Brodsky factor is based upon tritium, which is a highly volatile material that disperses readily. Experience with tritium, however, is not a valid predictor of the behavior of nonvolatile materials. Other forms of material are expected to be released in smaller amounts (Reference 6.12). This explains the need for the introduction of the release fractions as in Section 5.1.1.

The Brodsky factor was set forth as an "order of magnitude" estimation, not as a provable scientific truth. Because there are too many factors which vary unpredictably, Brodsky concluded that the probability of intake cannot be derived from theoretical situations or from experiments alone. The factor was presented as a boundary or a limitation on the inhalation of radioactive material that was rooted in practical experience (Reference 6.12).

To extrapolate the application of the Brodsky factor for use as the maximum fractional amount of throughput (or inventory) that is released into the air, one must recognize the relationship between inhalation and emissions. Per Reference 6.13 , the efficiency of inhaling dust particles is about $100 \%$ at $1 \mu \mathrm{m}, 90 \%$ at $10 \mu \mathrm{m}$, and about $50 \%$ for $35 \mu \mathrm{m}$ and larger particles. Since particles less than 10 microns are considered to be the respirable fraction and are also those which are most likely to become airborne, the distinction between probability of intake and probability of release becomes insignificant when the efficiency of inhalation is high. This is especially true when employing the Brodsky factor, which is proposed only as an "order of magnitude" factor. 


\subsubsection{Back-Calculation of Inventory}

NOTE: THIS SECTION HAS BEEN SUPERCEDED BY DOCUMENT NUMBER WSRC-TR-99-00126, DETERMINING ORIGINAL INVENTORY AMOUNT OF RADIOACTIVE SUBSTANCES FROM UNMONITORED RADIONUCLIDE EMISSIONS (U). WSRC-TR-99-00126 WAS CREATED TO REPLACE THE MATHEMATICAL FORMULA ORIGINALLY PRESENTED IN THIS SECTION IN ORDER TO DETERMINE BACK INVENTORY AMOUNTS OF RADIONUCLIDES. THE BODY OF WORK CONCERNING THE NEW FORMULA WITH EXAMPLES IS TOO EXPANSIVE AND BEYOND THE SCOPE OF THIS DOCUMENT FOR ITS INCLUSION TO TAKE PLACE.

Some situations may occur where the actual inventory of radionuclides is not known at the desired time, but a sample was taken at some point in time. From the sample, the emissions can be back calculated for the time of interest by the following equation.

$\mathrm{A}_{\mathrm{f}}=\mathrm{A}_{0}-\mathrm{A}_{\text {loss }}$

where $A_{0}=$ initial activity $(\mathrm{Ci})$

$\mathrm{A}_{\text {loss }}=$ activity lost between start and end of the time period of interest $(\mathrm{Ci})$

$A_{f}=$ final activity (the activity $(C i)$ at the time that the sample was taken).

The activity lost due to atmospheric releases ( $\left.A_{\text {release }}\right)$, not by decay, is given by

$\mathrm{A}_{\text {release }}=\mathrm{A}_{0} * \mathrm{R}$

where $R$ is the release fraction (the fraction of activity which is released). The release fractions used are described in Section 5.1.1 and provide "order of magnitude" estimates of release fraction.

The formula for radioactive decay is as follows.

$$
\mathrm{A}=\mathrm{A}_{0} e^{-\lambda t}
$$

where $A=\operatorname{activity}(C i)$ at time $t$.

$A=A_{f}$ when $t$ is the time between initial and final values $(\mathrm{t}=0)$.

$\lambda=$ decay constant $\left(\right.$ days $\left.^{-1}\right)=(\ln 2) / \theta_{1 / 2}$

$\theta_{1 / 2}=$ radioactive half-life (days).

The activity loss due to radioactive decay is given below.

$$
\begin{aligned}
A_{\text {decay }} & =A_{0}-A_{f} \\
& =A_{0}-A_{0} e^{-\lambda t} \\
& =A_{0}\left(1-e^{-\lambda t}\right)
\end{aligned}
$$

where $t$ (in days) is the time between the start and the end of the reference time period.
As is shown in the equations above, both radioactive decay and atmospheric releases (e.g., evaporation) lose activity. Some atoms decay and then their daughter products are released to the air while some atoms are released to the air and subsequently decay. Simply adding the release loss term to the decay loss term to get the total loss term would overestimate losses because the loss of some atoms (those that are both released and decay) would be counted twice. This "double" activity loss is equal to the initial activity multiplied by the probability that an atom would both decay and be released as shown below.

$\mathrm{A}_{\text {loss }}=\mathrm{A}_{0} * \mathrm{R} *\left(1-\mathrm{e}^{-\lambda \mathrm{t}}\right)$

The double loss activity must be subtracted from the sum of the separate release and decay losses to get the total activity loss as follows.

$\begin{aligned} A_{\text {loss }} & =A_{\text {release }}+A_{\text {decay }}-A_{\text {loss }} \\ & =A_{0} R+A_{0}\left(1-e^{-\lambda t}\right)-A_{0} R\left(1-e^{-\lambda t}\right)\end{aligned}$

Returning to the original formula and substituting gives

$A_{0}=A_{f} /\left[e^{\left.-\lambda t_{(1-R)}\right]}\right.$

When $A_{f}$ is known, the activity at some time previously, $A_{0}$ is easily calculated.

Assuming that all releases occur on the first day of the year, the most conservative estimate of the releases for the year can be made. Choosing the first day does not allow for radioactive decay during the year, but assumes that the entire inventory available for loss is released during the year (with no radioactive decay term). This conservative assumption then requires $t$ to be the number of days between the sample date and the beginning of the calendar year of interest. If previous years must be calculated from the same sample data, the time period $t$ is the number of years (expressed in days) the desired release estimate is from the last previously calculated January 1 value.

\subsubsection{Specific Activity (SpA)}

When inventory data is available in mass of each radionuclide rather than curies $(\mathrm{Ci})$, specific activity $(\mathrm{SpA})$ is used to convert the grams of each radionuclide to $\mathrm{Ci}$ as shown in the following equation.

Radionuclide Inventory $(\mathrm{Ci})=$ Radionuclide Inventory $(\mathrm{g}) * \mathrm{SpA}(\mathrm{Ci} / \mathrm{g})$

The specific activity of several radionuclides (in $\mathrm{Ci}$ per gram) can be found in 10 CFR 20 Appendix B or in Reference 6.10. Specific activity can also be calculated by the following equation based on the half-life (see Table 7.1) of the radionuclide (Reference 6.10). 
$\mathrm{SpA}(\mathrm{Ci} / \mathrm{g})=$

$\left(1.3^{*} 10^{8}\right) /[$ (half-life(days) $) *($ atomic weight $(\mathrm{g} /$ mole $\left.))\right]$

Often, data is given only in gross alpha and gross betagamma. Because Pu-239 is the alpha emitter with the longest half-life that has been handled at the SRS, gross alpha can be assumed to be represented by Pu-239, which has a specific activity of $6.13^{*} 10^{-2} \mathrm{Ci} / \mathrm{g}$. Since $\mathrm{Sr}-90$ is the beta-gamma emitter with the longest half-life, gross-beta gamma emissions are assumed to be represented by $\mathrm{Sr}-90$, which has a specific activity of $141 \mathrm{Ci} / \mathrm{g}$.

\subsection{Health Protection Air Sampling}

Sampling data can be used to estimate the atmospheric release of radionuclides from sources, such as those that were shut down and those that do not have an inventory of radionuclides except for residual contamination.

\subsubsection{Radionuclide Concentration in Facility Air}

The radionuclide concentration in the facility air is taken from air sampler data and has units of $\mu \mathrm{Ci} / \mathrm{cm}^{3}$. This is then converted to $\mathrm{Ci} / \mathrm{ft}^{3}$ by the following equation.

Radionuclide air concentration $\left(\mathrm{Ci} / \mathrm{ft}^{3}\right)=$ sample $\left(\mu \mathrm{Ci} / \mathrm{cm}^{3}\right)^{*}\left(\mathrm{Ci} / 10^{6} \mu \mathrm{Ci}\right) *\left(28,317 \mathrm{~cm}^{3} / \mathrm{ft}^{3}\right)$

This activity can be attributed to specific species of radionuclides based on process knowledge.

\subsubsection{Annual Air Flow}

When the exhaust rate is known, in cubic feet per minute, it is easily converted to cubic feet per year as follows.

$$
\begin{gathered}
\text { Air flow }\left(\mathrm{ft}^{3} / \mathrm{yr}\right)=\text { air flow }\left(\mathrm{ft}^{3} / \mathrm{min}\right) *(60 \mathrm{~min} / \mathrm{hr}) * \\
(8760 \mathrm{hr} / \mathrm{yr})
\end{gathered}
$$

Annual airflow can be estimated based on the assumption that a facility without forced ventilation undergoes 0.5 air exchanges per hour or 4380 air exchanges per year (Reference 6.3). The facility volume is needed for the calculation of annual airflow as shown in the following equation.

Annual air flow $\left(\frac{\mathrm{m}^{3}}{\mathrm{yr}}\right)=\left(\frac{4380 \mathrm{AC}}{\mathrm{yr}}\right) * \frac{\mathrm{Vol}\left(\mathrm{m}^{3}\right)}{\mathrm{AC}}$

where $\mathrm{AC}=$ Air Changes (or Air Exchanges) and $\mathrm{Vol}=$ the volume of the facility.

\subsubsection{Control Factor}

The control factor is an approximation of the radionuclide fraction not caught by any abatement equipment (filters, etc.) through which the facility air passes before release to the atmosphere. The control factors used here are the same as those discussed in Section 5.1.4. The application of the control factors when abatement equipment is in series or in parallel is also the same as in Sections 5.1.4.4 and 5.1.4.5. If the air does not pass through any abatement equipment prior to release to the atmosphere, the control factor is considered to be unity. This means that the uncontrolled and controlled release values are the same.

\subsubsection{Total Emissions}

The total uncontrolled and controlled annual air emissions are calculated from the previously discussed factors as follows.

uncontrolled release $(\mathrm{Ci} / \mathrm{yr})=$ radionuclide concentration $\left(\mathrm{Ci} / \mathrm{ft}^{3}\right) *$ air flow $\left(\mathrm{ft}^{3} / \mathrm{yr}\right)$

controlled release $(\mathrm{Ci} / \mathrm{yr})=$ uncontrolled release $(\mathrm{Ci} / \mathrm{yr})^{*}$ control factor

\subsection{Smear Data}

For some sources, such as non-point sources or inactive sources, an inventory of radionuclides except for residual contamination is typically not available. It is not possible to estimate emissions from these installations using the modified NUREG method. This approach is used frequently to estimate the atmospheric release of radionuclides from sources where an inventory could not be readily established but Health Protection smears are possible (Reference 6.3).

\subsubsection{Surface Contamination}

Smear data is an indicator of transferable radionuclide contamination. When smear samples undergo laboratory analysis and show less than minimum detectable concentrations (less than $10 \mathrm{dpm} / 100 \mathrm{~cm}^{2}$ of gross alpha and less than $80-\mathrm{dpm} / 100 \mathrm{~cm}^{2}$ of gross beta-gamma), the areas from which the smears are taken are considered "clean". That is, they have no transferable contamination. Accordingly, installations that are smeared and do not show transferable contamination, have no potential to emit and will not require subsequent evaluations unless conditions in the area change (Reference 6.3).

5.3.1.1 Smears analyzed with portable survey instruments provide less sensitive results than laboratory analysis. Depending on the survey instrument and the radiation background in which the smears are analyzed, the limits of detection for gross beta-gamma contamination may be as high as $10,000 \mathrm{dpm} / 100 \mathrm{~cm}^{2}$. The use of the measurements from these portable instruments should incorporate the conservative assumption that contamination is present at a level equal to the instrument's detection limit (Reference $6.3)$. 
5.3.1.2 In areas within a room or building where multiple smears show different levels of contamination, the highest level is used to estimate emissions from the entire area. Areas within a room or building that are not surveyed are assumed to have the highest level of transferable contamination that is detected elsewhere in the room (Reference 6.3).

5.3.1.3 Where transferable tritium contamination is detected, the entire surface area of a room (i.e., walls, floors, and ceilings) is used to estimate a source term. In the absence of information about specific radionuclides, it is assumed that gross beta-gamma is ${ }^{90} \mathrm{Sr}$ and the gross alpha is ${ }^{239} \mathrm{Pu}$ (Reference 6.3).

5.3.1.4 The surface contamination in $\mathrm{Ci} / \mathrm{m}^{2}$ is converted from smear data, which is usually reported as disintegrations $/ \mathrm{min} / 100 \mathrm{~cm}^{2}$ (i.e., $\mathrm{dpm} / 100 \quad \mathrm{~cm}^{2}$ ). Conversion to $\mathrm{Ci} / \mathrm{m}^{2}$ is then obtained by the following equation.

$\mathrm{SC}\left(\mathrm{Ci} / \mathrm{m}^{2}\right)=\operatorname{Sm}\left(\frac{\mathrm{dpm}}{100 \mathrm{~cm}^{2}}\right) *\left(\frac{\mathrm{Ci}}{2.22 * 10^{12} \mathrm{dpm}}\right) *\left(\frac{100^{2} \mathrm{~cm}^{2}}{\mathrm{~m}^{2}}\right)$

where $\quad S C=$ Surface Contamination and $\mathrm{Sm}=$ Measurement from smear.

\subsubsection{Resuspension factor}

5.3.2.1 The resuspension factor is the ratio of the radionuclide concentration in the facility air to the radionuclide concentration on the facility surface (e.g., the facility floor). It is made clear by the following equation that the resuspension factor has units of $\mathrm{m}^{-1}$ (References 6.1 and 6.11).

$\mathrm{RF}\left(\mathrm{m}^{-1}\right)=\frac{\left(\text { airborne radionuclides } / \mathrm{m}^{3}\right)}{\left(\text { surface radionuclides } / \mathrm{m}^{2}\right)}$

where $\quad \mathrm{RF}=$ Resuspension Factor. The resuspension factor is typically assumed to be $10^{-6}$ (Reference 6.1).

5.3.2.2 The radionuclide concentration in the facility air is then calculated by the following equation.

Radionuclide Concentration $\left(\frac{\mathrm{Ci}}{\mathrm{m}^{3}}\right)=\mathrm{SC}\left(\frac{\mathrm{Ci}}{\mathrm{m}^{2}}\right) * \mathrm{RF}\left(\frac{1}{\mathrm{~m}}\right)$

where $\quad \mathrm{SC}=$ Surface Contamination

$\mathrm{RF}=$ Resuspension Factor.

\subsubsection{Annual air flow}

Annual airflow is calculated as outlined in Section 5.2.2.

\subsubsection{Control Factor}

The control factor is an approximation of the radionuclide fraction not caught by any abatement equipment (filters, etc.) through which the facility air passes before release to the atmosphere. The control factors used here are the same as those discussed in Section 5.1.4. The application of the control factors when abatement equipment is in series or in parallel is also the same as in Sections 5.1.4.4 and 5.1.4.5. If the air does not pass through any abatement equipment prior to release to the atmosphere, the control factor is considered to be unity. This means that the uncontrolled and controlled release values are the same.

\subsubsection{Total Emissions}

The total uncontrolled and controlled air emissions are calculated from the previously discussed factors (or components) as follows.

Uncontrolled release $(\mathrm{Ci} / \mathrm{yr})=$ $\mathrm{SC}\left(\mathrm{Ci} / \mathrm{m}^{2}\right) * \mathrm{RF}\left(\mathrm{m}^{-1}\right) *$ Air flow $\left(\mathrm{m}^{3} / \mathrm{yr}\right)$

Controlled release $(\mathrm{Ci} / \mathrm{yr})=$

Uncontrolled release $(\mathrm{Ci} / \mathrm{yr}){ }^{*} \mathrm{CFtot}$

where CFtot is the control factor as described in Section 5.1.4.4.

\subsection{Emission Factors (EF)}

Emission factors can be used for the calculation of radionuclide emissions from basins due to liquid evaporation. The emission factors for any radionuclide other than tritium and Iodine-131 is $1 * 10^{-2}$. Tritium and I131 emission factors are 0.3 (Reference 6.3) and 0.5 (10 CFR 30.72 Schedule C), respectively. The releases of each radionuclide are calculated as follows.

Uncontrolled release $(\mathrm{Ci} / \mathrm{yr})=\mathrm{Liquid}$ Release $(\mathrm{Ci})^{*} \mathrm{EF}\left(\mathrm{yr}^{-1}\right)$

Controlled release $(\mathrm{Ci} / \mathrm{yr})=$

Uncontrolled release $(\mathrm{Ci} / \mathrm{yr}) * \mathrm{CF}$ tot

where CFtot is the control factor as described in Section 5.1.4.4.

\subsection{Dose Calculations}

The unabated source terms are converted to unabated EDE using SRS-specific radionuclide dose-release factors (mrem EDE per curie emitted) generated by the EPA computer code CAP-88. The dose factors are dependent upon the specific radionuclides present, the distance of the emission point from the site boundary, and the distance above the 
ground at which the release point is located. Potential EDE was calculated by multiplying the unabated source term by the associated radionuclide dose factor(s). Area and radionuclide specific dose-release factors can be found in Appendix D of Reference 6.5.

\subsection{REFERENCES}

6.1 Brodsky, A., Resuspension Factors and Probabilities of Intake of Material in Process (Or "Is $10^{-6}$ a Magic Number in Health Physics?"), Health Physics, Vol 39, pp 992-1000, 1980.

6.2 R. C. Weast, Ed. Handbook of Chemistry and Physics. 51st ed., Chemical Rubber Co., Cleveland (1970).

6.3 Savannah River Site Unmonitored Source Evaluations and Schedule for Confirmatory Measurements. ESH-ESG910667, Westinghouse Savannah River Company, Aiken, SC, (1991).

6.4 Title 40 CFR Part 61.93. Emission monitoring and test procedures.

6.5 Savannah River Site Potential Emissions Evaluation with Area Specific Dose Factors for Determination of Monitoring Requirements for the Radionuclide National Emission Standards For Hazardous Air Pollutants. (8/92).

6.6 Title 40 CFR Part 61.90. Designation of Facilities.

6.7 B. C. Blunt. National Emissions Standards for Hazardous Air Pollutants Quality Assurance Plan. USDOE Report WSRC-IM-91-60, Rev. 1, Savannah River Site, Aiken, SC 29808 (6/93).

6.8 Savannah River Site Radionuclide Annual Report for National Emissions Standards for Hazardous Air Pollutants (1991 Report), WSRC-IM-92-49, Savannah River Site, Aiken, SC 29808 (1992).

6.9 E. E. Hickey, G. A. Stoetzel, et. al., Air Sampling in the Workplace, NUREG 1400, USNRC, Washington, DC (1993).

6.10 The Health Physics and Radiological Health Handbook, Nucleon Lectern Associates, Olney, MD (1984).

6.11 W. E. Kennedy, Jr. and R. A. Peloquin, Residual Radioactive Contamination from Decommissioning, NUREG/CR--5512, USNRC, Washington, DC (1990).

6.12 E. E. Hickey, G. A. Stoetzel, et. al., Air Sampling in the Workplace, NUREG 1400, USNRC, Washington, DC,
Draft Report (1990).

6.13 J. K. Briant and A. C. James, Dissolution and Particle Size Characterization of Radioactive Contaminants in Hanford Facilities: Criteria for Methods of Measurement, PNL--7438, UC-602, USDOE, PNL, Richland, WA (1990).

6.14 A. R. Foster and R. L Wright, Basic Nuclear Engineering, 3rd ed., Allyn \& Bacon, Inc., Boston (1977).

6.15 Radiological Health Handbook, US Department of Health, Education, and Welfare, Public Health Service, FDA, Rockville, MD, (1970).

6.16 R. J. Lewis. Hawley's Condensed Chemical Dictionary. $12^{\text {th }}$ ed, Van Nostrand Reinhold Co., New York (1993). 


\subsection{ATTACHMENTS, FIGURES, AND}

TABLES

\begin{tabular}{|c|c|c|}
\hline Radionuclide & Half-Life & Specific Activity (Ci/g) \\
\hline Am-241 & $458 \mathrm{yr}$ & 3.24 \\
\hline $\mathrm{Ar}-41$ & $1.83 \mathrm{hr}$ & $4.17 \mathrm{E}+07$ \\
\hline $\mathrm{C}-14$ & $5.73 \mathrm{E}+03 \mathrm{yr}$ & 4.46 \\
\hline $\mathrm{Ce}-141$ & 32.8 day & $2.82 \mathrm{E}+04$ \\
\hline $\mathrm{Ce}-144$ & 284 day & $3.19 \mathrm{E}+03$ \\
\hline $\mathrm{Cm}-244$ & $17.6 \mathrm{yr}$ & 83.29 \\
\hline $\mathrm{Co}-58$ & 71.3 day & $3.16 \mathrm{E}+04$ \\
\hline $\mathrm{Co}-60$ & $5.26 \mathrm{yr}$ & $1.13 \mathrm{E}+03$ \\
\hline $\mathrm{Cr}-51$ & 27.8 day & $9.23 \mathrm{E}+04$ \\
\hline $\mathrm{Cs}-134$ & $2.05 \mathrm{yr}$ & $1.30 \mathrm{E}+03$ \\
\hline $\mathrm{Cs}-137$ & $30.0 \mathrm{yr}$ & 87.02 \\
\hline $\mathrm{Eu}-154$ & $16 \mathrm{yr}$ & 145.16 \\
\hline $\mathrm{H}-3$ & $12.3 \mathrm{yr}$ & $9.69 \mathrm{E}+03$ \\
\hline $\mathrm{l}-129$ & $1.7 \mathrm{E}+07 \mathrm{yr}$ & $1.63 \mathrm{E}-04$ \\
\hline $\mathrm{I}-131$ & 8.05 day & $1.24 \mathrm{E}+05$ \\
\hline $\mathrm{I}-133$ & $20.9 \mathrm{hr}$ & $1.13 \mathrm{E}+06$ \\
\hline $\mathrm{Kr}-85$ & $10.3 \mathrm{yr}$ & 408.53 \\
\hline $\mathrm{Kr}-85 \mathrm{~m}$ & $4.36 \mathrm{hr}$ & $8.42 \mathrm{E}+06$ \\
\hline $\mathrm{Kr}-87$ & $78 \mathrm{~min}$ & $2.80 \mathrm{E}+07$ \\
\hline $\mathrm{Mn}-54$ & 303 day & $7.98 \mathrm{E}+03$ \\
\hline $\mathrm{Nb}-95$ & 35 day & $3.93 \mathrm{E}+04$ \\
\hline $\mathrm{Np}-237$ & $2.14 \mathrm{E}+06 \mathrm{yr}$ & $7.05 \mathrm{E}-04$ \\
\hline $\mathrm{Pu}-238$ & $87.8 \mathrm{yr}$ & 17.12 \\
\hline $\mathrm{Pu}-239$ & $2.44 \mathrm{E}+04 \mathrm{yr}$ & $6.13 \mathrm{E}-02$ \\
\hline $\mathrm{Ru}-103$ & 39.8 day & $3.19 \mathrm{E}+04$ \\
\hline $\mathrm{Ru}-106$ & 367 day & $3.36 \mathrm{E}+03$ \\
\hline $\mathrm{Sb}-125$ & $2.7 \mathrm{yr}$ & $1.06 \mathrm{E}+03$ \\
\hline $\mathrm{Sr}-90$ & $28.1 \mathrm{yr}$ & 141.43 \\
\hline $\mathrm{U}-235$ & $7.1 \mathrm{E}+08 \mathrm{yr}$ & $2.14 \mathrm{E}-06$ \\
\hline $\mathrm{Xe}-133$ & 5.27 day & $1.86 \mathrm{E}+05$ \\
\hline $\mathrm{Xe}-133 \mathrm{~m}$ & 2.3 day & $4.27 \mathrm{E}+05$ \\
\hline $\mathrm{Xe}-135$ & $9.2 \mathrm{hr}$ & $2.52 \mathrm{E}+06$ \\
\hline $\mathrm{Zn}-65$ & 245 day & $8.20 \mathrm{E}+03$ \\
\hline $\mathrm{Zr}-95$ & 65 day & $2.11 \mathrm{E}+04$ \\
\hline
\end{tabular}

